\title{
Inefficiency in the fight against wildlife crime in Brazil
}

\author{
Ednaldo Monteiro da Silva and Enrico Bernard
}

\begin{abstract}
Brazil's biodiversity faces significant threats, including wildlife crime. Although wildlife is protected by law and there are enforcement agencies to administer penalties and impose fines, the effectiveness of this system is questionable. Tackling wildlife crime requires legislation aligned with well-structured mechanisms for surveillance and de facto punishment. We used data on notifications of violations and payment of fines associated with wildlife crime in the state of Pernambuco over 12 years as a proxy for efficiency in tackling wildlife crime in Brazil. We tracked 803 processes from 2000-2012, extracting data on the type of violation, the fine imposed, the length of process handling, and processing and payment status. The number of processes rose from 17 in 2004 to 167 in 2012, with 69\% of cases occurring during 2008-2012. Only 37.6\% of processes were concluded, with completion times of $286-4,558$ days. Some processes had been open for 11.5 years. Fines totalling $>$ USD 22 million were issued but only c. 1\% of this amount was paid. Small fines are often pardoned or converted to a warning. Although enforcement has improved it is still inefficient, with errors in notification and data entry, a lengthy judicial process, and an inability to recover unpaid fines.
\end{abstract}

Keywords Biodiversity, Brazil, environmental enforcement, environmental policies, public policies, wildlife crime

\section{Introduction}

$\mathrm{B}$ razil's biodiversity is protected by law, including the B 1998 Environmental Crimes Law (Presidência da República do Brasil, 1998), which was a significant legal step for the protection of wildlife and for the punishment of perpetrators of wildlife crime. In Brazil wildlife crime includes keeping animals in captivity without legal permits, hunting and killing wild animals, removing animals from the wild, selling or exporting wildlife illegally, and abusing

Ednaldo Monteiro da Silva and Enrico Bernard (Corresponding author) Laboratório de Ciência Aplicada à Conservação da Biodiversidade, Departamento de Zoologia, Centro de Ciências Biológicas, Universidade Federal de Pernambuco, Recife, PE 50670-420, Brazil

E-mail enrico.bernard@ufpe.br

Received 9 September 2014. Revision requested 24 October 2014

Accepted 11 November 2014. First published online 9 January 2015. or mutilating animals (Presidência da República do Brasil, 2008). Keeping wild animals as pets is a practice deeply rooted in Brazilian culture (e.g. Alves et al., 2013), making surveillance and enforcement difficult and time-consuming. The official strategy for dealing with wildlife crime in Brazil is based predominantly on the command and control approach and is often inefficient (Regueira \& Bernard, 2012).

Brazil has a three-tiered political and administrative system, comprising the Federal government, states and municipalities, which together form the Federative Republic of Brazil (Presidência da República do Brasil, 1988). The 26 states and one federal district are semi-autonomous selfgoverning entities, with their own constitutions and governments, and the 5,570 municipalities are minor federal units, with autonomous local governments. According to the National Constitution, each administrative level should have its own executive agencies, including those for dealing with environmental issues (Presidência da República do Brasil, 1988). Until 2011, the National Institute of Environment and Renewable Natural Resources (Instituto Nacional do Meio Ambiente e dos Recursos Naturais Renováveis, IBAMA) was responsible for surveillance and enforcement of all administrative penalties involving wildlife crime in Brazil. This responsibility was transferred to state environmental agencies by Federal Law 140 (Presidência da República do Brasil, 2011a) but several states are not yet prepared to take full responsibility for their wildlife.

Success in tackling wildlife crime requires environmental legislation aligned with well-structured mechanisms for surveillance and de facto punishment (Brito \& Barreto, 2005). Despite the existence of specific laws for wildlife protection in Brazil, their effectiveness is questionable (e.g. Alves \& Pereira Filho, 2007; Alves \& Rosa, 2010; Regueira \& Bernard, 2012; Kuhnen \& Kanaan, 2014), and the few data available indicate low rates of crime investigation, effective judgement, and punishment (Brito \& Barreto, 2005, 2006; Barreto et al., 2009a, b). We use data on notifications of violations and on the payment of fines associated with wildlife crime, collected during a 12-year period in the state of Pernambuco, as a proxy for efficiency in tackling wildlife crime in Brazil. Pernambuco is a source and hub for trafficked animals in north-eastern Brazil, supplying illegal markets in the south and south-east (RENCTAS, 2001; Pereira \& Brito, 2005; Regueira \& Bernard, 2012). The local framework for environmental surveillance and 
enforcement is similar to that in most other states, and thus our data may be indicative of the overall situation in the country.

\section{Study area}

Pernambuco state $\left(98,311 \mathrm{~km}^{2}\right)$ comprises 185 municipalities, with a total population of 9.2 million. Circa 3.6 million inhabitants are concentrated in the metropolitan area around the capital, Recife, where per capita income is USD 6,806 (IBGE, 2014). IBAMA has two offices in Pernambuco: the main one in Recife and a second in Salgueiro.

\section{Methods}

Under Brazil's law on access to information (Presidência da República do Brasil, 2011b) we submitted a request via IBAMA's citizen information system for all notifications of violations against wildlife (hereafter processes) recorded in Pernambuco state during January 200o-December 2012. We also searched for processes on IBAMA's database Public Consultation on Environmental Notifications and Embargoes.

The citizen information system returned 884 processes, and 15 others were added based on the search in the public consultation database. We analysed all 899 processes and discarded 96 because it was impossible to identify if they were directly related to wildlife crime (66), there were no data in the system (20), or the crimes were clearly not related to wildlife (10). Our final sample comprised 803 processes. We then used IBAMA's processes database to check the status of each process, extracting, if possible, the following data: process number; type of violation (as specified in Decree 6.514/2008; Presidência da República do Brasil, 2008); date of violation and value of the fine imposed; any reference to taxa and numbers of specimens; date of recording of the process in the database; date of the last process handling; processing status (concluded or in progress); duration of processing and/or conclusion; and payment status (paid, pardoned, expired or unknown). We considered as concluded all processes in which the fine had been paid, pardoned or expired, or those for which court proceedings had been issued to recover the fines. The payment status was considered unknown for processes that had been concluded but were under legal challenge, or for which it was not possible to determine whether the fine had been paid. All values were converted to USD based on the currency exchange rate of USD 1.00 = BRL 2.04 as of December 2012.

\section{Results}

We identified various problems with the data and, in some cases, a lack of information needed for appropriate handling

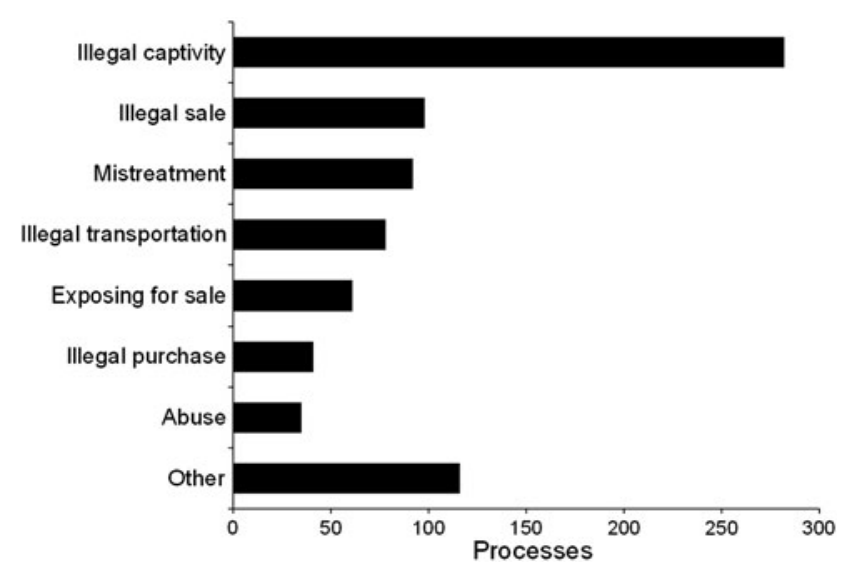

FIG. 1 Numbers of processes issued by Instituto Brasileiro do Meio Ambiente e dos Recursos Naturais Renováveis (IBAMA) against perpetrators of various types of wildlife crime in the state of Pernambuco, north-eastern Brazil, during January 2000December 2012.

of the processes: in 32 processes $(3.99 \%)$ the date of entry in the database was incorrect; 29 processes (3.61\%) did not include the name or document number of the transgressor; 17 (2.12\%) indicated a fine of USD o.0o; 401 (49.94\%) had no information on the taxon involved; and 355 (44.21\%) did not indicate the number of specimens involved. The overall quality of the data has improved since $2008: 82.28 \%$ of the processes with data on taxa and $88.17 \%$ of those indicating the number of specimens are concentrated in the last 4 years of the sample.

We found 416 indications of taxa in 412 processes: 351 $(84.38 \%)$ involved birds, $52(12.50 \%)$ mammals, and 13 $(3.12 \%)$ reptiles, crustaceans and fish. Keeping wild animals in captivity $(35.12 \%)$, illegal trade in wildlife $(12.20 \%)$, and mistreating animals (11.46\%) were the most common crimes (Fig. 1).

The number of processes varied from 17 in 2004 to 167 in 2012, with an annual mean of 66.91 (Fig. 2). The period 2008-2012 accounted for $69.36 \%$ of processes. The mean time between the date of issue of a process and its entry into the database varied from 1,509 days (2000) to 7 days (2009 and 2012). The mean time for completion of a process varied from 3,265 days (2000) to 191 days (2012; Fig. 3). Of the 803 processes considered, $501(62.39 \%)$ were still in progress in December 2012 and 302 (37.61\%) had been concluded. The oldest of the concluded processes, issued in 2000 , had been in progress for 4,213 days. Ninety processes $(17.96 \%)$ had been in progress for at least 5 years and, of these, $24(26.67 \%)$ had been in progress for $>10$ years.

During 2000-2012 USD 22,029,755 in fines were issued in Pernambuco for crimes against wildlife (Table 1). Fines varied from USD 500 (107 processes) to USD 5,170,000 (3). Of the 803 processes analysed 67 fines were paid (8.34\%), 84 were pardoned $(10.46 \%)$, nine expired $(1.12 \%)$, and 142 


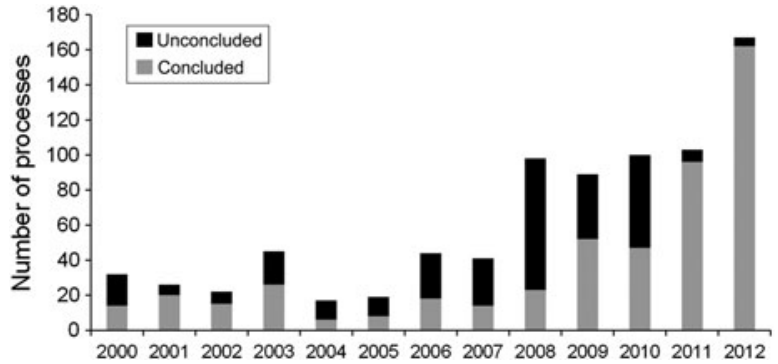

FIG. 2 Temporal distribution and status of 803 processes issued by IBAMA against perpetrators of wildlife crime in the state of Pernambuco, north-eastern Brazil, during January 2000December 2012

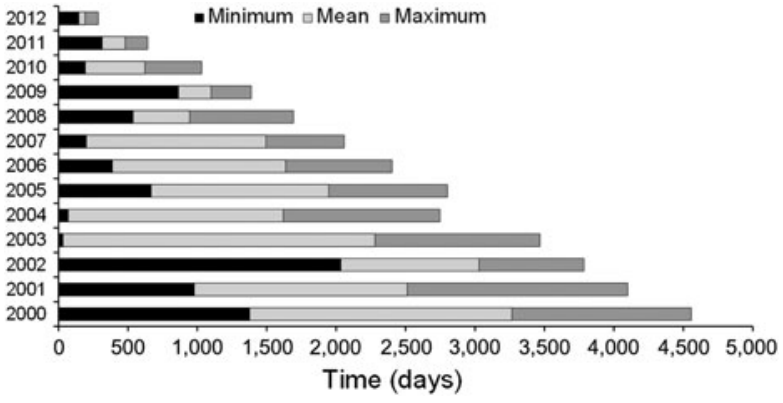

FIG. 3 Minimum, mean and maximum time (in days) for the conclusion of processes issued by IBAMA against perpetrators of wildlife crime in the state of Pernambuco, north-eastern Brazil, during January 2000-December 2012. Of 803 processes analysed only 302 had been concluded by December 2012 .

TABLE 1 Status of legal proceedings issued by Instituto Brasileiro do Meio Ambiente e dos Recursos Naturais Renováveis (IBAMA) in the state of Pernambuco, north-eastern Brazil, during January 2000-December 2012.

\begin{tabular}{|c|c|c|c|c|c|c|c|c|c|c|}
\hline \multirow[b]{2}{*}{ Year } & \multicolumn{2}{|c|}{ Processes } & \multicolumn{2}{|c|}{ Pardoned } & \multicolumn{2}{|c|}{ Expired } & \multicolumn{2}{|c|}{ Unknown status } & \multicolumn{2}{|l|}{ Paid } \\
\hline & No. & Value (USD) & No. & Value, USD (\%) & No. & Value, USD (\%) & No. & Value, USD (\%) & No. & Value, USD (\%) \\
\hline 2000 & 32 & 423,828 & 3 & $4,883(1.15)$ & 5 & $47,363(11.18)$ & 5 & $49,316(11.64)$ & 5 & $2,930(0.69)$ \\
\hline 2001 & 26 & 293,701 & 2 & $20,752(7.07)$ & 1 & $2,441(0.83)$ & 1 & $244(0.08)$ & 2 & $977(0.33)$ \\
\hline 2002 & 22 & 104,639 & 1 & $488(0.47)$ & 0 & $0(0)$ & 4 & $4,297(4.11)$ & 2 & $3,662(3.5)$ \\
\hline 2003 & 45 & 321,777 & 6 & $1,221(0.38)$ & 1 & $1,465(0.46)$ & 4 & $9,766(3.04)$ & 8 & $123,047(38.24)$ \\
\hline 2004 & 17 & 60,156 & 2 & $0(0)$ & 0 & $0(0)$ & 7 & $49,902(82.95)$ & 2 & $488(0.81)$ \\
\hline 2005 & 19 & 82,275 & 1 & $0(0)$ & 0 & $0(0)$ & 6 & $4,639(5.64)$ & 4 & $6,348(7.72)$ \\
\hline 2006 & 44 & 309,814 & 7 & $0(0)$ & 1 & $8,301(2.68)$ & 13 & 42,725 (13.79) & 5 & $4,395(1.42)$ \\
\hline 2007 & 41 & 312,227 & 2 & $0(0)$ & 1 & $2,441(0.78)$ & 20 & $103,242(33.07)$ & 4 & $3,906(1.25)$ \\
\hline 2008 & 98 & 376,709 & 38 & $42,480(11.28)$ & 0 & $0(0)$ & 25 & $115,430(30.64)$ & 12 & $21,484(5.7)$ \\
\hline 2009 & 89 & $1,600,195$ & 7 & $1,709(0.11)$ & 0 & $0(0)$ & 24 & $153,320(9.58)$ & 6 & $51,514(3.22)$ \\
\hline 2010 & 100 & 530,762 & 12 & $4,639(0.87)$ & 0 & $0(0)$ & 31 & $331,055(62.37)$ & 10 & 8,789 (1.66) \\
\hline 2011 & 103 & $8,637,012$ & 3 & $1,221(0.01)$ & 0 & $0(0)$ & 2 & $77,637(0.9)$ & 2 & $732(0.01)$ \\
\hline 2012 & 167 & $8,976,660$ & 0 & $0(0)$ & 0 & $0(0)$ & 0 & $0(0)$ & 5 & $4,639(0.05)$ \\
\hline Total $^{*}$ & 803 & $22,029,755$ & 84 & $77,393(0.35)$ & 9 & $62,011(0.28)$ & 142 & $941,573.00$ & 67 & $232,911.00$ \\
\hline
\end{tabular}

${ }^{\star}$ Including concluded processes

were of unknown payment status (17.68\%; Table 1). The amount paid in fines during the 12-year period was USD 232,911 , just $1.06 \%$ of the total issued. Excluding 2011 and 2012, for which most of the processes were still in progress, the rate of success in the collection of fines varied from $0.33 \%$ (2001) to $38.56 \%$ (2003; Table 1). Sixty-nine percent of the fines paid were $\leq$ USD 980 (Fig. 4). In December 2012 IBAMA Pernambuco had 511 processes in progress (excluding those of unknown payment status), amounting to outstanding fines of USD $20,715,867$.

\section{Discussion}

We found a significant degree of inefficiency in the federal system of surveillance and punishment of crimes against wildlife administered by IBAMA in Pernambuco state. Although enforcement has increased, the time frame for process handling and judgement in many cases still exceeds the legal limits. As a result the rate of collection of fines is low: of c. USD 22 million in fines issued during 20002012 only c. $1 \%$ was collected. This inefficiency is a consequence of a combination of errors in data entry, omissions of information necessary for the correct handling of processes, the slowness of the Brazilian justice system, and the public administration's lack of capacity to collect unpaid debts.

We found data entry errors in nearly $9 \%$ of the processes analysed, which can result in the cancellation of fines, although the overall quality has improved since 2008 . Similar problems have been identified in other regions of Brazil. A study on illegal deforestation in the Brazilian Amazon revealed that $5 \%$ of 55 processes administered by IBAMA during 1999-2002 had data entry errors that resulted in the need to reissue the notification, or prevented prosecution (Brito \& Barreto, 2006). In 2012 IBAMA 


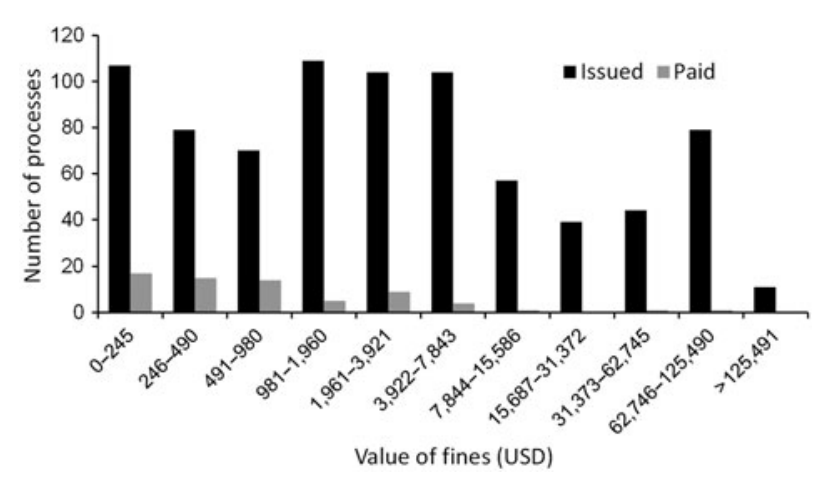

FIG. 4 Distribution of value of fines issued by IBAMA against perpetrators of wildlife crime in the state of Pernambuco, north-eastern Brazil, during January 200o-December 2012. Of 803 processes analysed only 67 fines had been paid by December 2012.

adopted an electronic reporting system, which is contributing to the reduction of such errors (IBAMA, 2013).

Handling and judgement times were reduced progressively during 2000-2012, partly as a result of changes in legislation, with a reduction in the number of appeals allowed and the establishment of screening teams to deal with simpler processes (Presidência da República do Brasil, 2008; IBAMA, 2009). Despite such efforts there is a backlog of uncompleted processes and the judicial system continues to be slow. Environmental agencies often require the judiciary to collect fines on their behalf, and therefore slow trials result in low revenue (e.g. Barreto et al., 2009b). Reports of the National Council of Justice (Conselho Nacional de Justiça) indicate that 92 million cases were processed by the Brazilian justice system in 2012, only $30 \%$ of which were completed (CNJ, 2013). The slow rate of progress has been attributed to various factors, including the probability of appeals, the lack of civil servants, judges and infrastructure, the state bureaucracy, the low level of digital processing, and limited budgets (Zampier, 2013).

Analyses of efficiency in the collection of fines are rare in the Brazilian federal government but should be adopted as a standard audit mechanism, to increase transparency in the public administration and improve the effectiveness of national enforcement bodies (TCU, 2013a). According to a study on deforestation in Pará state during 1999-2002 only $15 \%$ of 55 cases were concluded and paid (accounting for c. $3 \%$ of the total fines), whereas $74 \%$ of cases were sentenced but remained unpaid, accounting for $78 \%$ of the total fines (Brito \& Barreto, 2006). In the state of Mato Grosso, analysis of 421 fines issued during 2005-2006 (229 by IBAMA and 192 by the State Secretary for the Environment) revealed that by March 2008 only $1 \%$ of the fines had been paid (Brito, 2009). IBAMA's poor performance is recognized and its overall collection rate is one of the lowest among public agencies in Brazil. During 2008-2012 IBAMA had more fines issued than any other federal agency in Brazil (c. USD 8 billion; $35 \%$ of total federal fines) but its collection rate (o.6\%) was the worst among 17 public agencies analysed (TCU, 2010, 2013b).

Such inefficiency has negative consequences for biodiversity. Firstly, the state is failing to collect taxes that could be used to fund environmental agencies and programmes. The Brazilian Ministry of Environment, which funds IBAMA, has one of the smallest budgets of Brazil's ministries and has undergone consecutive budget cuts since 2006 (Menezes \& Chagas, 2012). During 2005-2010, throughout the country, IBAMA issued nearly USD 314 million in fines for crimes against fauna, but during the same period it received $<2 \%$ of that amount in fines paid (Bennett, 2012). Failing to realize such important sources of funding is unwise, considering cuts in budgets for conservation programmes and the creation and maintenance of protected areas (Bruner et al., 2004; McCarthy et al., 2012; Hanson \& McNair, 2014).

Secondly, such a low rate of revenue is indicative of bad governance in the environmental sector, which may have a direct impact on the success of conservation efforts (Smith et al., 2003). Environmental governance should be a priority, given Brazil's dependence on the agribusiness and mining sectors, which have significant environmental impacts. Instead, however, there have been reversals in long-standing environmental achievements (e.g. Schwartzman et al., 2012; Novaes \& Souza, 2013; Bernard et al., 2014).

More importantly, poor governance sends the wrong message to society (that crimes against wildlife may be committed with impunity) and this may influence the decisionmaking of potential offenders (Gordon et al., 2009). A lack of will to prosecute may stem from the fact that illegal activities such as hunting and keeping wild birds are strongly rooted in local culture in some areas (Alves \& Pereira Filho, 2007; Regueira \& Bernard, 2012; Alves et al., 2013). If the law were enforced it would result in a high number of prosecutions. Historically, however, there has been an erroneous view that crimes against wildlife are minor and therefore warrant light sentences. Furthermore, with the possibility of pardoning or conversion of fines, transgressors may go unpunished (Barreto \& Mesquita, 2009). In this way the Brazilian justice system fails to convey the message that biodiversity has an intrinsic and irreplaceable value that should be considered and respected.

Other studies have suggested that it is difficult for surveillance and enforcement systems against wildlife crime to function correctly in places where the culture is poorly aligned with conservation, and there is a need to seek alternative solutions, such as market-based mechanisms, social marketing or education (Jepson \& Ladle, 2005, 2009). It may be necessary to focus surveillance and enforcement on threatened species and key personnel involved in wildlife trafficking. 
In 2011 legal responsibility for surveillance and enforcement of administrative penalties involving flora, fauna and environmental licensing was transferred from IBAMA to state and municipal environmental agencies (Presidência da República do Brasil, 2011a). Such decentralization could be expected to have positive effects on conservation of ecosystems, by empowering local authorities to protect their natural resources. However, we believe this move will be deleterious to conservation in Brazil. Pernambuco and several other states are not yet prepared to take full responsibility for enforcement against wildlife crime, lacking qualified personnel and/or the necessary infrastructure facilities. Since 2007 IBAMA has accelerated the closure of several of its offices (e.g. Clark, 2011; Farias, 2011; IBAMA, 2012), transferring responsibility for enforcement to states or, in some cases, unprepared municipalities. The transition has given rise to territorial and temporal gaps in a system of surveillance and enforcement that is already insufficient to safeguard the country's biodiversity. To prevent further damage we recommend that the transfer of responsibilities from IBAMA should be conducted gradually, only after states and municipalities have acquired the necessary expertise, qualified personnel and infrastructure.

\section{Acknowledgements}

We thank the Department of Zoology at Universidade Federal de Pernambuco for supporting our research, Maria Eduarda Larrazabal and Felipe Pimentel Lopes de Melo for their role in evaluating EMS's BSc honours thesis, and Richard Ladle and Rômulo Alves for their constructive comments.

\section{References}

Alves, R.R.N., Lima, J.R.F. \& Araújo, H.F.P. (2013) The live bird trade in Brazil and its conservation implications: an overview. Bird Conservation International, 23, 53-65.

Alves, R.R.N. \& Pereira Filho, G.A. (2007) Commercialization and use of snakes in north and northeastern Brazil: implications for conservation and management. Biodiversity and Conservation, 16, 969-985.

Alves, R.R.N. \& Rosa, I.L. (2010) Trade of animals used in Brazilian traditional medicine: trends and implications for conservation. Human Ecology, 38, 691-704.

Barreto, P., Araújo, E. \& Brito, B. (2009a) A impunidade de crimes ambientais em áreas protegidas federais na Amazônia. Imazon, Belém, Brazil.

Barreto, P. \& Mesquita, M. (2009) Como prevenir e punir infrações ambientais em áreas protegidas na Amazônia? Imazon, Belém, Brazil.

Barreto, P., Mesquita, M., Araújo, E. \& Brito, B. (2009b) A impunidade de infratores ambientais em áreas protegidas da Amazônia. Imazon, Belém, Brazil.

BennetT, W.F. (2012) Where the wild things were. Http://10or.org/ 2012/11/where-the-wild-things-were/ [accessed 8 September 2014].
Bernard, E., Penna, L.A.O. \& Araújo, E. (2014) Downgrading, downsizing, degazettement, and reclassification of protected areas in Brazil. Conservation Biology, 28, 939-950.

Brito, B. (2009) Multas Pós-Operação Curupira no Mato Grosso. Imazon, Belém, Brazil.

Brito, B. \& Barreto, P. (2005) Desafios da Lei de Crimes Ambientais no Pará. Imazon, Belém, Brazil.

Brito, B. \& B Arreto, P. (2006) A eficácia da aplicação da lei de crimes ambientais pelo Ibama para proteção de florestas no Pará. Revista de Direito Ambiental, 32, 35-65.

Bruner, A.G., Gullison, R.E. \& Balmford, A. (2004) Financial costs and shortfalls of managing and expanding protected-area systems in developing countries. BioScience, 54, 1119-1126.

Clark, N. (2011) Ibama pretende desativar unidades regionais no país. Http://www.oeco.org.br/noticias/25203-ibama-pretende-desativarunidades-regionais-no-pais [accessed 8 September 2014].

CNJ (Conselho Nacional de Justiça) (2013) Justiça em números 2013: ano-base 2012. Http://www.cnj.jus.br/images/pesquisasjudiciarias/Publicacoes/relatorio_jn2013.pdf [accessed 8 September 2014].

Farias, E. (2011) Municípios do Amazonas ficam desassistidos com fechamento de unidades do Ibama. Http://acritica.uol.com.br/ amazonia/Amazonia-Amazonas-Manaus-Municipios-Amazonasdesassistidos-fechamento-Ibama_o_593340995.html [accessed 8 September 2014].

Gordon, M.B., Iglesias, J.R., Semeshenko, V. \& Nadal, J.P. (2009) Crime and punishment: the economic burden of impunity. The European Physical Journal B, 68, 133-144.

Hanson, J.H. \& McNaIR, D. (2014) Should conservationists continue to dodge the issue of tax dodging? Oryx, 48, 313-314.

ibama (Instituto Brasileiro do Meio Ambiente e dos Recursos Naturais Renováveis) (2009) Instrução Normativa no 14, de 15 de maio de 2009. Http://www.ibama.gov.br/category/1? download $=58 \% 3$ A14-2009-p-27-2009\&start $=40$ [accessed 8 September 2014].

ibama (Instituto Brasileiro do Meio Ambiente e dos Recursos Naturais Renováveis) (2012) Relatório de Gestão do Exercício de 2011. Http://www.ibama.gov.br/phocadownload/acesso_ a_informacao/ibama_relatorio_de_gestao_2011.pdf [accessed 8 September 2014].

ibama (Instituto Brasileiro do Meio Ambiente e dos Recursos Naturais Renováveis) (2013) Implementação do Auto de Infração Eletrônico-AI-e. Http://www.ibama.gov.br/publicadas/ implementacao-do-auto-de-infracao-eletronico- $\% \mathrm{E} 2 \% 80 \% 93$-ai-e [accessed 8 September 2014].

ibGE (Instituto Brasileiro de Geografia e estatística) (2014)Estados@Pernambuco. Http://www.ibge.gov.br/estadosat/ perfil.php?sigla=pe [accessed 3 December 2014].

Jepson, P. \& Ladle, R.J. (2005) Bird-keeping in Indonesia: conservation impacts and the potential for substitution-based conservation responses. Oryx, 39, 442-448.

Jepson, P. \& LAdLE, R.J. (2009) Governing bird-keeping in Java and Bali: evidence from a household survey. Oryx, 43, 364-374.

Kuhnen, V.V. \& KanaAn, V.T. (2014) Wildlife trade in Brazil: a closer look at wild pets welfare issues. Brazilian Journal of Biology, 74, 124-127.

McCarthy, D.P., Donald, P.F., Scharlemann, J.P.W., Buchanan, G.M., Balmford, A., Green, J.M.H. et al. (2012) Financial costs of meeting global biodiversity conservation targets: current spending and unmet needs. Science, 338, 946-949.

Menezes, D. \& Chagas, P.V. (2012) Meio Ambiente: $27 \%$ do orçamento é "contingenciado". Http://www.contasabertas.com.br/ website/arquivos/1101 [accessed 8 September 2014]. 
Novaes, R.L.M. \& Souza, R.F. (2013) Legalizing environmental exploitation in Brazil: the retreat of public policies for biodiversity protection. Tropical Conservation Science, 6, 477-483.

Pereira, G.A. \& Brito, M.T. (2005) Diversidade de aves silvestres brasileiras comercializadas nas feiras livres da Região Metropolitana do Recife, Pernambuco. Http://www.ao.com.br/download/glauco. pdf [accessed 8 September 2014].

PresidênCia da República do Brasil (1988) Constituição da República Federativa do Brasil de 1988. Http://www.planalto.gov.br/ ccivil_03/constituicao/Constituicao.htm [accessed 3 November 2014].

Presidência da República do Brasil (1998) Lei no 9.605, de 12 de fevereiro de 1998. Http://www.planalto.gov.br/ccivil_03/leis/l9605. htm [accessed 8 September 2014].

Presidência da República do Brasil (2008) Decreto no 6.514 de 22 de julho de 2008. Http://www.planalto.gov.br/ccivil_03/_ato20072010/2008/decreto/D6514.htm [accessed 8 September 2014].

PresidênCia da República do Brasil (2011a) Lei Complementar no 140, de 8 de dezembro de 2011. Http://www.planalto.gov.br/ccivil_03/ leis/lcp/Lcp140.htm [accessed 8 September 2014].

Presidência da República do Brasil (2011b) Lei no 12.527, de 18 de novembro de 2011. Http://www.planalto.gov.br/ccivil_03/_ato20112014/2011/lei/l12527.htm [accessed 8 September 2014].

REGUEIRA, R.F.S. \& BERNARD, E. (2012) Wildlife sinks: quantifying the impact of illegal bird trade in street markets in Brazil. Biological Conservation, 149, 16-22.

RenCtas (Rede Nacional de Combate ao Tráfico de Animais Silvestres) (2001) $1^{\circ}$ Relatório Nacional sobre o Tráfico de Fauna Silvestre. Http://www.renctas.org.br/wp-content/uploads/ 2014/o2/REL_RENCTAS_pt_final.pdf [accessed 8 September 2014].

Schwartzman, S., Moutinho, P. \& Hamburg, S. (2012) Amazon deforestation and Brazil's forest code: a crossroads for climate change. Carbon Management, 3, 341-343.
Smith, R.J., Muir, R.D.J., Walpole, M.J., Balmford, A. \& Leader-Williams, N. (2003) Governance and the loss of biodiversity. Nature, 426, 67-70.

TCU (Tribunal de Contas da União) (2010) Relatório e Parecer Prévio sobre as Contas do Governo da República: Exercício de 2009. Http://portal2.tcu.gov.br/portal/page/portal/TCU/comunidades/ contas/contas_governo/contas_og/Textos/CG\%202009\%20Relat\% C3\%B3rio.pdf [accessed 8 September 2014].

TCU (Tribunal de Contas da União) (2013a) Referencial básico de governança: aplicável a órgãos e entidades da administração pública. Http://portal2.tcu.gov.br/portal/pls/portal/docs/2642557. PDF [accessed 8 September 2014].

TCU (Tribunal de Contas da União) (2013b) Relatório e Parecer Prévio Sobre as Contas do Governo da República: Exercício de 2012. Http://portal2.tcu.gov.br/portal/page/portal/TCU/comunidades/ contas/contas_governo/Contas2012/fichas/CG\%202012\%20Relat\% C3\%B3rio\%2oSess\%C3\%A30_Web.pdf [accessed 8 September 2014].

ZAMPIER, D. (2013) Questões processuais e falta de pessoal motivam lentidão da Justiça, dizem presidentes de tribunais. Http:// agenciabrasil.ebc.com.br/noticia/2013-02-22/questoes-processuaise-falta-de-pessoal-motivam-lentidao-da-justica-dizem-presidentesde-tribunais [accessed 8 September 2014].

\section{Biographical sketches}

EDNALDO DA SiLva's studies focus on environmental sciences and, in particular, on quantifying the impact of wildlife crime. ENRICO BERNARD leads the Laboratory of Applied Biodiversity Conservation Science at the Department of Zoology, Federal University of Pernambuco, and his interests are focused on conservation biology. 